\title{
Allogeneic Hematopoietic Stem Cell Transplantation
}

National Cancer Institute

\section{Source}

National Cancer Institute. Allogeneic Hematopoietic Stem Cell Transplantation. NCI

Thesaurus. Code C46089.

A clinical treatment in which hematopoietic stem cells (HSCs) are transferred from one genetically dissimilar individual to another. 